\title{
SISTEM PENDIDIKAN PESANTREN BERBASIS TAKHASSUS AN-NASYRI UNTUK MENGEMBANGKAN PENDIDIKAN KARAKTER SISWA
}

\author{
Zaki Mubarok \\ ${ }^{1}$ Institut Agama Islam Negeri Kudus \\ Isonggo@gmail.com
}

\begin{abstract}
ABSTRAK
Pondok Pesantren Darul Falah memiliki kegiatan-kegiatan yang bernuansa keagamaan, yang paling terkenal adalah kegiatan riyadhoh puasa dalail khairot. Seakan-akan Pondok Pesantren Darul Falah memiliki jimat yang kiranya perlu diteliti agar segala proses yang diterapkan oleh Podok Pesantren Darul Falah bisa di publikasikan sebagai acuan dan pertimbangan bagi peneliti sendiri secara pribadi dan masyarakat luas pada umumnya. Adapun tujuan penelitian ini adalah untuk mengetahui bagaimana langkah-langkah sistem pendidikan pesantren berbasis takhassus an-nasyri dan faktor apa saja yang mendukung dan yang menghambat terhadap keberhasilan pengasuh pondok pesantren dalam mengembangkan pendidikan karakter di pondok pesantren Darul Falah Jekulo Kudus dalam mengembangkan pendidikan karakter. Oleh karena itu peran pesantren dan juga sistem pendidikannya sangat menentukan bagi terciptanya lulusan yang mempunyai jiwa berkarakter. Hasil penelitian menunjukkan bahwasanya santri maupun alumni yang sudah tamat dari pendidikan Takhassus di Pondok Pesantren Darul Falah tidak hanya memiliki bekal keilmuan yang matang akan tetapi jiwa karakter seperti cinta tuhan beserta ciptaannya, karakter percaya diri, jiwa kepemimpinan dan toleransi terhadap perbedaan yang melekat pada dirinya.
\end{abstract}

Kata Kunci: Sistem Pendidikan, Takhassus, Mengembangkan Pendidikan Karakter

\begin{abstract}
Darul Falah Islamic boarding school has religious activities, the most famous of which is the riyadhoh fasting dalail khairot activity. It is as if Darul Falah Islamic Boarding School has a talisman that needs to be examined so that all processes applied by the Darul Falah Islamic Boarding School can be published as a reference and consideration for the researcher himself and the wider community in general. The purpose of this study is to
\end{abstract}


IO8 | Tarbawi : Jurnal Pendidikan Islam Vol. 18. No. I. Januari - Juni 202I

find out how the steps of the takhassus an-nasyri-based pesantren education system and what factors support and hinder the success of boarding school caregivers in developing character education at the Darul Falah Jekulo Kudus Islamic boarding school in developing character education. Therefore, the role of pesantren and its education system is crucial for the creation of graduates who have a soul of the character. The results showed that students and alumni who have graduated from Takhassus education at Darul Falah Islamic Boarding School do not only have mature scientific provisions but have a soul of characters such as love of God and its creations, self-confident character, leadership spirit, and tolerance for differences inherent in themselves.

Keywords: Steps of the Education, Takhassus, Developing Character Education.

\section{PENDAHULUAN}

Manusia adalah sosok yang dinamis baik sebagai pendidik, peserta didik maupun penanggung jawab pendidikan. Pembahasan konsep pendidikan selalu berkembang dan tidak akan habis dibicarakan oleh masyarakat khususnya di lembaga pendidikan, karena semakin tua dunia maka akan semakin pentingnya dunia pendidikan.

Kebutuhan manusia akan pendidikan merupakan suatu yang sangat mutlak dalam hidup ini, dan manusia tidak bisa dipisahkan dari kegiatan pendidikan. Jhon Dewey mengatakan bahwa pendidikan merupakan kebutuhan hidup manusia guna membantu dan mempersiapkan pribadinya agar hidup lebih disiplin (Fatah Yasin, 2010).

Berdasarkan Undang-undang Republik Indonesia Nomor 20 Tahun 2003 tentang Sistem Pendidikan Indonesia Nasional, ditetapkan dalam Bab I, Pasal 1, ayat 1 bahwa "pendidikan adalah usaha sadar untuk menyiapkan peserta didik melalui kegiatan bimbingan pengajaran atau latihan bagi peranannya di masa yang akan datang" (Kahar Usman: -,14). Pendidikan Nasional (SISDIKNAS) pada pasal 3 yang berbunyi "Pendidikan nasional berfungsi mengembangkan kemampuan dan membentuk karakter serta peradaban bangsa yang bermartabat dalam rangka mencerdaskan kehidupan bangsa (Sutarjo Adisusilo, 2013). Sedangkan tujuan dasar awal pendidikan pesantren adalah mencetak kader ulama dan mendukung tersebarnya ajaran Islam ke wilayah yang lebih luas (Achmad Muchaddam Fahham, 2015). 
Di era globalisasi ini, pergolakan dunia dikawal oleh ekonomi, militer, teknologi dan informasi adalah tantangan serius dunia Islam. Ironis lagi, moralitas dan mentalitas umat sudah banyak yang terkena virus barat, jauh dari norma dan tuntunan agama. Sumber utama realitas ini jelas kembali kepada sumber daya manusia (SDM) umat yang masih dilanda kebodohan. Oleh karena itu satu-satunya jalan cepat untuk membangkitkan umat dari keterbelakangan ini adalah optimalisasi sektor pendidikan. Lembaga ini sangat penting eksistensi dan efektifitasnya dalam rangka memompa semangat belajar anak manusia mengejar ketertinggalan untuk mencapai taraf hidup yang maju dengan tetap dalam misi menegakkan keadilan, kesetaraan dan kedamaian umat manusia (M. Affan Hasyim, 2003).

Terdapat dampak dari perkembangan ilmu dan teknologi, juga mempengaruhi terhadap banyaknya masalah dalam usaha dan proses peningkatan kualitas pendidikan baik pada tataran konsep maupun tataran praktiknya, apalagi kalau dihubungkan dengan asumsi bahwa problem-problem pendidikan sebenarnya berpangkal dari kurang kokohnya landasan filosofis pendidikannya. Sehingga kajian mengenai konsep pendidikan yang dilontarkan para ahli merupakan keharusan (Santri Lirboyo, 2015).

Bangsa kita, seperti saat ini telah kehilangan kearifan lokal yang menjadi karakter budaya bangsa sejak berabad-abad lalu. Seperti maraknya kasus tawuran antar pelajar, antar mahasiswa dan antar kampung. Tindak korupsi di semua lini kehidupan dan institusi. Maka tidak heran jika pembentukan dan pembinaan karakter bangsa menuju masyarakat yang bermoral, berbudi pekerti luhur dan menjunjung tinggi nasionalisme laksana kapal tanpa pedoman di tengah luasnya samudra (Agus Wibowo. 2013).

Mengenai fenomena yang terjadi sekarang ini, terutama melemahnya karakter pribadi masing-masing orang maka peran pesantren maupun para guru harus dapat menunjukkan kontribusi dan actionnya, terutama untuk membawa keberhasilan implementasi pendidikan karakter. Dari didikan mereka akan terlahir peserta didik paripurna (insan kamil) yang tidak saja cerdas secara kognitif, tetapi juga dalam sikap (afektif) dan perbuatan (psikomotorik) ((Agus Wibowo. 2013).

Pendidikan karakter dimaknai sebagai pendidikan nilai, pendidikan budi pekerti, pendidikan moral, pendidikan watak yang bertujuan mengembangkan kemampuan peserta didik untuk memberikan keputusan baik-buruk, memelihara apa yang baik dengan sepenuh hati (Nur Said, 2016). Oleh karena itu pendidikan ala pesantren 
menawarkan satu konsepsi yang jelas dalam penanaman karakter anak didiknya. Menurut penelitian Arifin (2014) tradisi pesantren telah mampu memadukan moralitas ke dalam sistem pendidikan dalam skala yang luar biasa kuatnya. Di dunia pesantren pendidikan karakter bukanlah hal yang baru, sebab sejak dini meanstream karakter santri sudah dikedepankan melalui pendidikan akhlak. Di pesantren persoalan akhlak menjadi persoalan yang sangat urgen, sebenarnya pesantren telah lama mendidik santrinya agar memiliki karakter yang dapat diandalkan, seperti karakter bidang keilmuan, karakter bidang akhlak dan karakter bidang sosial. Sehingga sejarah mencatat, kedaulatan Indonesia tidak lepas dari peran para ulama, kyai, santri dan alumni pondok pesantren. Para pahlawan yang memperjuangkan perlawanan atas penjajah dimulai dari peluit pesantren. Dikala masyarakat dilanda ketimpangan perbudakan, dikala rakyat berhamburan akibat penjajahan, maka instruksi dari Kyai selalu menjadi pemersatu untuk mencapai kemerdekaan dan perlawanan selalu bermula dari petunjuk Sang Kyai (Nur Said, 2016).

Salah satu bentuk institusi pendidikan keagamaan Islam di Indonesia adalah pondok pesantren. Institusi ini memiliki system pendidikan yang unik sehingga berbeda dengan institusi pendidikan keagamaan lainnya, seperti madrasah. Keunikan system pendidikan pesantren oleh Abdurrahman Wahid disebut dengan istilah subkultur, sementara Zamakhsari Dhofier menyebut keunikan system pendidikan pesantren itu dengan istilah tradisi pesantren (Achmad Muchaddam Fahham, 2015).

Setiap lembaga pendidikan, termasuk pesantren dituntut untuk memberikan pelayanan sebaik mungkin kepada pelanggan-pelanggannya. Agar dapat melakukan hal tersebut dengan baik, pesantren perlu dukungan sistem manajemen yang baik. Beberapa ciri sistem manajemen yang baik adalah adanya pola pikir yang teratur (administrative thinking), pelaksanaan kegiatan yang teratur (administrative behavior), dan penyikapan terhadap tugas-tugas kegiatan secara baik (administrative attitude) (Matsuki, 2008).

Titik acuan Pesantren yang maju, tidaklah dilihat hanya dari banyaknya santri atau bangunan Pondok yang megah. Namun Pesantren itu terasa hidup jika di dalamnya terdapat proses pembelajaran yang secara aktif antara ulama' (guru) dengan santri (peserta didik). Tanpa adanya pembelajaran, maka pesantren akan terlihat mati. Karena Pesantren dinilai memilki tanggung jawab yang tinggi, selain membentuk pribadi santri yang memiliki keunggulan dalam bidang keilmuan Islam, 
pesantren bertanggung jawab dalam membentuk santri yang berkarakter (Nizar Ali \& Ibi Syabiti, 2009).

Pondok Pesantren Darul Falah Jekulo Kudus yang merupakan pondok tertua kedua setelah pondok al-Qaumaniyah (Pondok Bareng 1923) yang didirikan oleh K.H. Yasin.Pondok Darul Falah ini, masih kental dengan para santri yang berta'allum mendalami ilmu-ilmu diniyyah. Pendiri Pondok Pesantren Darul Falah adalah K.H. Ahmad Basyir yang merupakan santri dari K.H. Yasin. Setelah beliau mengabdi lama (sejak lulus dari SD hingga dewasa) kepada K.H.Yasin, akhirnya beliau disuruh untuk mendirikan pondok sendiri yang berada di sebelah barat Pondok gurunya. Tepatnya di sebelah utara Masjid Baitussalam.

Pondok pesantren salafy yang terkenal dengan pengamal Dalail Khoirot ini juga tidak menafikan perkembangan zaman. Tetap menjaga nilai-nilai lama dan mengambil nilai-nilai baru yang lebih baik, seperti halnya maqolah dibeberapa kitab, Artinya: "Melestarikan (nilai-nilai) lama yang relevan dan mengadopsi (metode) baru yang lebih relevan". Dalil ini diterapkan dengan adanya kegiatan Takhassus An-Nasyri, sebagai bentuk pelestarian cara mengajar para ulama' di pesantren menggunakan bandongan, sorogan, musyawarah, hafalan. Juga mengambil nilai baru yaitu dengan menerapkan sistem perkelasan.

Takhassus An-Nasyri ini dibagi menjadi 6 kelas. Setiap kelas materi yang diajarkanpun berbeda, sesuai dengan tingkatan kelasnya (kemampuan santri). Materi yang diajarkannya tidak hanya pada satu bidang keilmuan saja dan sesuai dari tingkat kemampuan santri itu. Terkadang ada santri yang telah dewasa, namun tingkat kemampuan memahami materi maupun akhklaknya masih kurang, sehingga masih perlu bimbingan dari dasar. Adapun materi-materi yang digunakan di pesantren Darul Falah untuk memahami pengetahuan agama maupun membentuk karakter siswa meliputi; bidang fiqih, Akhlak, Alqur"an, Tajwid, Tauhid, Hadits, Tasawuf, Ushul Fiqih, IImu Alat (Nahwu \& Shorof), dan IImu Mantiq. Bidang-bidang keilmuan inipun diajarkan kepada santri sesuai tingkat pemahamannya.

Ada sesuatu yang unik di dalam Takhassus An-Nasyri ini, yaitu ketika tes ujian akhir di kelas 6 yaitu tes membaca kitab Fathul Mu'in di hadapan para pengasuh dengan menggunakan pengeras suara dilaksanakan di pondok putri. Merupakan suatu hal untuk menguji mental seorang santri. Jika membacanya bisa baik dan lancar merupakan sebagai prestasi, tetapi jika membacanya masih terbata-bata dan kurang lancar maka akan menjadi minus tersendiri bagi santri itu. Akan tetapi selain 
II2 | Tarbawi : Jurnal Pendidikan Islam Vol. 18. No. I. Januari - Juni 202I

mengedepankan pemahaman akan kitab-kitab salaf yang begitu dibutuhkan, pendidikan karakter jauh lebih penting dibandingkan itu. Karena kondisi sekarang ini lebih dari sebagian muda mudi di masyarakat akhlaknya telah digerus oleh zaman. Sehingga penulis lebih terfokus untuk meneliti tentang system pendidikan pesantren berbasis takhassus an-nasyri untuk mengembangkan pendidikan karakter siswa di pondok ini.

Pada masa ini kebudayaan semakin berkembang pesat. Akan tetapi justru akhlaq dan moral generasi bangsa semakin mengalami kemerosotan. Jika tidak dibekali dengan ilmu dan iman yang kuat, maka generasi muda yang akan datang menjadi generasi lemah. Dari segi akhlaqnya, para pemuda saat ini mengalami krisis akhlaqul karimah. Sikap tawadhu' yang seharusnya dimiliki, justru menjadi sebaliknya. Yang paling bertanggung jawab terhadap degradasi moral bangsa adalah umat islam. Karena mayoritas penduduk Indonesia adalah orang Islam. Nilai-nilai keislaman harus ditanamkan sejak kecil.

Pengetahuan tentang agama dapat diperoleh di lembaga formal maupun lembaga non-formal. Di lembaga formal yaitu sekolah diberikan mulai dari pendidikan paling rendah sampai jenjang tertinggi. Sedangkan pada lembaga non-formal pendidikan agama diperoleh melalui Madrasah Diniyyah maupun pondok pesantren.

Orangtua memasukkan anaknya ke pondok pesantren biasanya disertai dengan harapan agar si anak mempunyai ilmu agama yang bagus, berakhlaq mulia dan memahami hukum-hukum Islam. Selama ini tidak ada kekhawatiran bahwa dengan menuntut ilmu di pesantren akan menjauhkan kasih-sayang orangtua terhadap anak. Anak yang tinggal di pondok pesantren dalam waktu cukup lama tetap bisa beridentifikasi kepada kedua orangtuanya. Dengan menjalin komunikasi secara intens dan teratur diharapkan anak tidak akan kehilangan figur orangtua.

Dari sinilah peneliti tertarik untuk melakukan penelitian terhadap system pendidikan pondok pesantren dalam rangka mencari sesuatu yang belum tersentuh dan tidak terpikirkan oleh sebagian besar sistem pendidikan Islam di Indonesia. Penelitian ini bergulat dengan refleksi pendidikan Islam di Pondok Pesantren dalam bentuk system pendidikannya yang berbasis takhassus an-nasyri. Salah satu tujuannya untuk menyadarkan masyarakat akan pentingnya pendidikan karakter siswa di dunia ini serta menciptakan pemahaman pendidikan Islam yang lebih progresif konstekstual sehingga mampu menjawab tantangan zaman. 


\section{METODE PENELITIAN}

Jenis penelitian yang dipakai adalah penelitian lapangan (field reseach). Yaitu kegiatan penelitian yang dilakukan di lingkungan masyarakat tertentu, baik di lembaga dan organisasi kemasyarakatan maupun lembaga pemerintah, dengan cara mendatangi rumah tangga, perusahaan-perusahaan, dan tempat-tempat lainny. Usaha pengumpulan datanya langsung dengan cara wawancara dan observasi (Mahmud, 2011). Pendekatan yang digunakan dalam penelitian ini adalah pendekatan kualitatif, karena pendekatan ini untuk meneliti kondisi obyek yang alami,dan datanya sesuai fakta terjadi sebagaimana adanya, bukan data yang sekedar terlihat, terucap, akan tetapi data yang mengandung makna di balik yang terlihat dan terucap tersebut, serta instrumen kuncinya ialah peneliti itu sendiri (Mahmud, 2011). Penelitian ini untuk menggambarkan realitas tentang pelaksanaan pembelajaran Takhassus an-Nasyri di pondok pesantren Darul Falah Jekulo Kudus.

Adapun pengumpulan data dari penelitian ini menggunakan dua sumber yaitu sumber data primer dan sumber data sekunder (Mahmud, 2011). Penelitian ini dilaksanakan di Pondok Pesantren Darul Falah Jekulo Kudus. Penulis menggunakan beberapa metode untuk mendapatkan data yang relevan dan valid guna menjawab permasalahan yang diajukan dalam penelitian ini, diantaranya, metode observasi, metode interview, dan metode dokumentasi.

\section{PEMBAHASAN}

Sebelum membahas sistem pendidikan pesantren berbasis takhassus annasry, terlebih dahulu akan dijelaskan beberapa pengertian dari sistem, teori-teori pendidikan dan sistem pendidikan di Indonesia yang penulis kutip dari pendapat para ahli antara lain. Menurut Kamus Besar Bahasa Indonesia (KBBI). Dalam Kamus Besar Bahasa Indonesia dinyatakan bahwa sistem berarti perangkat unsur yang secara teratur saling berkaitan sehingga membentuk suatu totalitas, susunan yang teratur dari pandangan, teori, asas dan sebagainya. Sistem juga diartikan dengan metode (Muhammad Aulia, 2002). Sedangkan menurut Ludwig, sistem adalah seperangkat unsur yang saling berhubungan dan saling mempengaruhi dalam satu lingkungan tertentu. Sedangkan Budi Sutedjo, sistem adalah kumpulan elemen yang saling berhubungan satu sama lain yang membentuk satu kesatuan dalam usaha mencapai suatu tujuan (Eti Rochaety, 2005). Sedangkan menurut Ki Hajar Dewantara pendidikan adalah daya upaya untuk memajukan bertumbuhnya budi pekerti 
(kekuatan batin, karakter), pikiran (intelek dan tubuh anak) (Qiqi Yuliati, 2014). Sedangkan menurut Imam Ghazali pendidikan adalah proses pembiasaan (riyadhoh). Artinya upaya untuk menumbuhkan respons pada siswa melalui pembimbingan secara emosi dan fisik. Proses pembiasaan (riyadhoh) adalah membantu siswa menuju tempat tujuan tertinggi (aqsha al-ghayah) (Sarbini, 2011).

Dalam sistem pendidikan di Indonesia Bab I Pasal 1 UU SISDIKNAS no. 20 tahun 2003 disebutkan bahwa Sistem Pendidikan Nasional adalah keseluruhan komponen pendidikan yang saling terkait secara terpadu untuk mencapai tujuan pendidikan nasional. Tujuan pendidikan nasional yang dirumuskan dalam UU SISDIKNAS adalah untuk mengembangkan potensi anak didik agar menjadi manusia yang beriman dan bertakwa kepada Tuhan Yang Maha Esa, berakhlak mulia, sehat, berilmu, cakap, kreatif, mandiri, dan menjadi warga Negara yang demokratis serta bertanggung jawab. Adapun komponen-komponen dalam pendidikan nasional antara lain adalah lingkungan, sarana-prasarana, sumberdaya, dan masyarakat. Komponenkomponen tersebut bekerja secara bersama-sama, saling terkait dan mendukung dalam mencapai tujuan pendidikan. Di samping komponen-komponen tersebut pendidikan juga meliputi aspek-aspek sistemik lainnya yaitu: Isi, Proses, dan Tujuan

Implementasi dari aspek pendidikan isi adalah input (anak didik) sebagai obyek dalam pendidikan, sedangkan proses/trasformasi merupakan mesin yang akan mencetak anak didik sesuai yang diharapkan, dan Tujuan merupakan hasil akhir yang dicapai atau output. Perlu diketahui bahwa proses/ trasformasi dalam kerjanya dipengaruhi oleh berbagai factor, seperti fasilitas, waktu, lingkungan, sumber daya, pendidik dan sebagainya, dimana faktor tersebut sangat menentukan output. Oleh karena itu sebuah sistem pendidikan perlu melakukan penyesuaian dengan lingkungan, karena lingkungan mengandung sejumlah kendala bagi bekerjanya sistem (misalnya: keterbatasan sumber daya). Untuk itu sistem pendidikan dituntut oleh lingkungan untuk mengolah sumber daya pendidikan secara efektif dan efisien.

Dengan demikian jelaslah bahwa makna pendidkan sebagai sistem adalah seluruh komponen yang ada dalam pendidikan (seperti lingkungan, masyarakat, sumber daya) dapat bekerja sama dalam mencapai tujuan pendidikan pendidikan nasional, yang dalam implementasinya dapat dilihat dari aspek-aspek sistem yaitu input-proses-output, dan hasil akhir dari output dapat memberikan umpan balik terhadap input dan proses sehingga dapat diketahui hasil akhir tujuan pendidikan (Munirah, 2015). Kalau dicermati mengenai tujuan sisitem pendidikan nasional 
menurut Sisdiknas 2003 di atas, dapat di simpulkan bahwa pendidikan agama mempunyai posisi yang sangat penting dalam pendidikan nasional. Pendidikan agama lebih menfokuskan diri dalam membentuk peserta didik secara aktif mengembangkan potensi dirinya untuk memiliki kekuatan spiritual keagamaan dan ketakwaan kepada Tuhan Yang Maha Esa.

Sedangkan dalam pandangan sistem pendidikan pesantren, salah satu bentuk institusi pendidikan keagamaan Islam di Indonesia adalah pondok pesantren. Institusi ini memiliki system pendidikan yang unik sehingga berbeda dengan institusi pendidikan keagamaan lainnya, seperti madrasah. Keunikan system pendidikan pesantren oleh Abdurahman Wahid disebut dengan istilah subkultur, sementara Zamakhsari Dhofier menyebut keunikan system pendidikan pesantren dapat dilihat pada elemen-elemen pembentuk tradisinya, seperti masjid, pondok, kitab-kitab klasik keagamaan dan kiai. Di samping itu keunikan system pendidikan ini juga dapat dilihat dari tipologi, tujuan, fungsi, prinsip pembelajaran, kurikulum, dan metode pembelajarannya (Achmad Muchaddam Fahham, 2015). Menurut M Arifin system pendidikan pesantren adalah sarana yang berupa perangkat organisasi yang diciptakan untuk mencapai tujuan pendidikan yang berlangsung dalam pesantren. Menurut M Arifin pesantren memiliki karakteristik diantaranya (a) masjid, (b) pondok, (c) kiai atau pengasuh, (d) santri, (e) pengajaran kitab kuning. Menurut M Arifin ada juga metode pembelajaran yang terdapat di pesantren, diantaranya (a) sorogan, (b) wetonan atau bandongan, (c) metode hiwar atau musyawarah (Rohadi Abdul Fatah, 2008).

Sistem Pendidikan Pesantren Berbasis Takhassus An-Nasryi. Ma'had takhassus merupakan lembaga pendidikan keagamaan yang berfungsi mempersiapkan peserta didik untuk menjadi ahli agama (mutadayyin), selain juga merupakan benteng terakhir untuk mempertahankan "nilai dan tradisi kepesantrenan", seperti kemandirian, tradisi keilmuan, dan kesederhanaan. Penyelenggaraan Ma"had Takhassus ini sesuai dengan undang-undang No.20 Tahun 2003 tentang Sistem Pendidikan Nasional yang mengamanatkan bahwa pendidikan keagamaan yang berfungsi mempersiapkan peserta didik menjadi anggota masyarakat yang memahami dan mengamalkan nilai-nilai ajaran agamanya dan/atau menjadi ahli ilmu agama dapat diselenggarakan pada jalur pendidikan formal, non formal dan informal. Keberadaan Ma'had Takhassus yang bersifat non formal dan otonom pun kini diakui undang-undang, berdasarkan Peraturan Pemerintah No. 19 tentang Standar Nasional 
Pendidikan (Pasal 93) (Asnawi, 2009). Ma'had Takhassus merupakan jalur pendidikan tinggi Islam non formal yang tidak terstruktur dan pelaksanaannya dapat berjenjang serta diselenggarakan sesuai kekhasan masing-masing lembaganya (Asnawi, 2009). Takhassus an-Nasyri sendiri dilaksanakan secara non formal dan sesuai kekhasan Pondok Pesantren Darul Falah Jekulo Kudus.

Secara umum, tujuan penyelengggaraan pendidikan Ma'had Takhassus adalah menghasilkan sumber daya manusia yang memiliki kualifikasi keahlian di bidang Agama Islam dengan penguatan berbasis kompetensi ilmu agam tertentu (Aqidah, Tafsir, Hadits, Fiqh-Ushul Fiqh) melalui pelestarian dan pengembangan tradisi keilmuan Islam klasik (turats al-salaf) untuk selanjutnya diaplikasikan bagi kemaslahatan masyarakat (Asnawi, 2009). Jadi Ma"had Takhassus ini lebih menekankan untuk menyiapkan para santri ketika terjun di masyarakat dengan bekal ilmu agama yang mumpuni.

Adapun penyelenggaraannya Ma'had Takhassus ini menggunakan kurikulum yang fleksibel yaitu disusun oleh masing-masing penyelenggara Ma"had Takhassus (lembaga itu sendiri) dan semuanya terdiri dari ilmu-ilmu agama Islam. Mata pelajarannya pun berbasis pada al-kutub al-turats (kitab kuning). Kitab kuning yang diberikan dibagi menjadi dua komponen yaitu kitab inti (dimusyawarahkan) dan kitab penunjang (tidak dimusyawarahkan) (Asnawi, 2009). Untuk tingkat I yang menjadi kitab inti itu adalah kitab Fiqih (Taqrib/ Fathul Qarib), sedangkan untuk tingkat II yaitu kitab Fiqih (Fathul Mu'in/ Fathul Wahab). Selain kedua kitab ini maka digunakan sebagai kitab penunjang (tidak dimusyawarahkan).

Dalam proses pembelajarannya Ma"had Takhassus menggunakan pendekatan dan metode pembelajaran tersendiri. Pendekatan yang digunakan ada 3 yaitu;

a. Pendekatan Tekstual, yaitu memahami nushush secara lughawiyah, harfiyah, dan tarkibiyah. Hal ini ditempuh dengan dua cara, yaitu al-tadris (bimbingan kyai) dan mudarosah (diskusi).

b. Pendekatan Kontekstual, yaitu memahami nushush secara cermat dan dititikberatkan pada maqashid al-syar"iah dengan telaah kritis (al-naqd). Kajian ini dilakukan secara lintas madzhab dan diimplementasikan dalam bentuk karya tulis, hasil studi naskah, dan lain-lain.

c. Pendekatan Naqdiyah (kritis), yaitu melatih diri untuk mencoba melihat beberapa karya para imam mujtahid dengan muqabalatu al-kutub al-qadimah wa al-mu"ashirah (komparasi kitab-kitab klasik dan referensi kontemporer). 
Selain pendekatan di atas, Ma'had Takhassus menggunakan tiga model pembelajaran, yaitu model studi sorogan, model klasikal, dan model kuliah umum. Adapun penjelasannya sebagai berikut;

a. Metode Sorogan, adalah model pembelajaran yang mirip mentoring sistem, di mana santri diajak memahami kandungan kitab secara perlahan-lahan secara detail dengan mengikuti pikiran dan konsep-konsep yang termuat di dalam kitab. Kata demi kata. Dalam metode ini, santri diberikan kebebasan untuk memilih ustadz yang hendak memandunya.

b. Metode Klasikal yaitu proses pembelajaran yang dilakukan di dalam kelas sesuai dengan kurikulum yang tersedia untuk masing masing jenjang. Metode ini seringkali digunakan sebagaii sarana diskusi atau musyawarah antara para santri. Adapun guru atau ustadz berperan sebagai pemandu atau fasilitator dalam proses diskusi dan musyawarah

b. Metode kuliah umum yaitu sistem pembelajaran yang berupa pengajian yang dilakukan di Masjid dan biasanya dipandu oleh pengasuh pondok pesantren (Asnawi, 2009).

Berbicara soal karakter, maka perlu disimak apa yang ada dalam UU nomor 20 Tahun 2003 tentang System Pendidikan Nasional (SISDIKNAS) pada pasal 3 yang berbunyi " Pendidikan nasional berfungsi mengembangkan kemampuan dan membentuk karakter serta peradaban bangsa yang bermartabat dalam rangka mencerdaskan kehidupan bangsa (Sutarjo Adisusilo, 2013).

Dalam kamus besar bahasa Indonesia $(\mathrm{KBBI})$ kata karakter diartikan sebagai tabiat, tingkah laku, sifat-sifat kejiwaan, akhlak atau budi pekerti yang membedakan seseorang dengan orang lain (Agus Wibowo, 2013). Sedangkan menurut S.M Dumadi karakter berasal dari bahasa yunani "charassein" yang berarti barang atau alat untuk menggores, yang dikemudian hari dipahami sebagai stempel/cap. Jadi karakter atau watak itu adalah sebuah stempel/cap, sifat-sifat yang melekat pada seseorang (Sutarjo Adisusilo, 2013).

Adapun tujuan Pendidikan Karakter, menurut Kemendiknas, tujuan pendidikan karakter adalah mengembangkan potensi kalbu/nurani/afektif peserta didik sebagai manusia dan warga negara yang memiliki nilai-nilai budaya dan karakter bangsa, Mengembangkan kebiasaan dan perilaku peserta didik yang terpuji dan sejalan dengan nilai-nilai universal dan tradisi budaya bangsa yang religious (Kemendiknas, 
2010). Menurut Ratna Megawangi, ada Sembilan pilar karakter yang layak diajarkan kepada peserta didik dalam konteks pendidikan karakter:

1. Cinta Tuhan dan segenap ciptaannya

2. kemandirian dan tanggung jawab

3. kejujuran dan amanah

4. hormat dan santun

5. Dermawan, suka menolong, dan gotong royong

6. Percaya diri, kreatif dan pekerja keras

7. Kepemimpinan dan keadilan

8. Baik dan rendah hati

9. Toleransi, kedamaian, dan kesatuan (Ahmad Muhaddam Faham, 2015).

Pendidikan karakter dimaknai sebagai pendidikan nilai, pendidikan budi pekerti, pendidikan moral, pendidikan watak yang bertujuan mengembangkan kemampuan peserta didik untuk memberikan keputusan baik-buruk, memelihara apa yang baik dengan sepenuh hati. Oleh karena itu pendidikan ala pesantren menawarkan satu konsepsi yang jelas dalam penanaman karakter anak didiknya (Nur Said, 2016).

Dengan demikian pendidikan karakter yang telah dikemukakan oleh beberapa tokoh dapat disimpulkan sebagaimana berikut "Pendidikan yang menitikberatkan nilai keperibadian seseorang dengan membentuk kepribadian menjadi mandiri dan tanggung jawab, jujuran dan amanah, hormat dan santun, dermawan, suka menolong, dan gotong royong, percaya diri, kreatif dan pekerja keras, kepemimpinan dan keadilan, baik dan rendah hati serta toleransi dalam segala kondisi.

\section{SIMPULAN}

Setelah peneliti menguraikan pembahasan tentang penelitian yang berjudul "Sistem Pendidikan Pesantren Berbasis Takhassus An-Nasyri Untuk Mengembangkan Pendidikan Karakter Siswa (Studi Kasus Di Pondok Pesantren Darul Falah Jekulo Kudus) Tahun Ajaran 2019/2020". Maka dapat ditarik kesimpulan sebagai berikut: (1) Pondok Pesantren Darul Falah Jekulo Kudus merupakan pondok pesantren yang menerapkan metode pembelajaran tradisional dan klasikal. Tetapi jika dilihat dari substansinya Pondok Pesantren Darul Falah lebih menggunakan sistem pendidikan yang basisnya adalah takhassus an-nasyri. Sistem pendidikan ini memuat metode pembelajaran yang sifatnya klasikal, yakni sorogan, bandongan, hafalan dan musyawarah serta menyuguhkan materi yang sifatnya tidak hanya keagamaan saja 
akan tetapi keduniaan juga. (2) Langkah-langkah yang ditempuh oleh Pengasuh Pondok Pesantren Darul Falah adalah dengan memberikan materi-materi penunjang kepada para santri agar lebih mudah dan cepat dalam membaca dan memahami kitab kuning. Para Pengasuh Pondok Pesantren Darul Falah juga menerapkan beberapa metode pembelajaran dalam menunjang prestasi belajar santri membaca kitab kuning, yaitu dengan menggunakan metode wetonan (ngaji bandongan), sorogan, musyawarah dan hafalan.

Sistem pendidikan yang ditampilkan dalam Pondok Pesantren Darul Falah mempunyai keunikan dibandingkan dengan system yang diterapkan dalam lembaga pendidikan pada umumnya, yaitu: (1) Memakai system tradisional, yang memiliki kebebasan penuh dibandingkan dengan sekolah modern, sehingga terjadi hubungan 2 arah antara Kyai dan santri. (2) Sistem pendidikan pondok pesantren mengutamakan asas yang berdasarkan sebagai penunjang dalam mengembangkan karakter di kemudian hari seperti, cinta tuhan dan seluruh ciptaanNya kesederhanaan, persaudaraan, persamaan, rasa percaya diri, keberanian hidup, dan toleransi.

\section{DAFTAR PUSTAKA}

Adisusilo, Sutarjo, 2013, Pembelajaran Nilai Karakter, Jakarta: PT Radja Grafindo Persada.

Asnawi, 2009, Pedoman Penyelenggaraan Pesantren Takhassus, Jakarta: Departemen Agama RI.

Fahham, Achmad Muchaddam, 2015, Pendidikan Pesantren, Yogyakarta: Azza Grafika.

Fahham, Achmad Muchaddam, Pendidikan Pesantren, 2015, Pola Pengasuhan, Pembentukan Karakter dan Perlindungan Anak, Yogyakarta: P3DI Setjen DPR RI dan Azza Grafika.

Fatah, Rohadi Abdul,dkk, 2008, Rekonstruksi Pesantren Masa Depan, Jakarta: PT Listafariska.

Hasyim, M. Affan, 2003, Menggagas Pesantren Masa Depan, Yogyakarta: Qirtas.

Kemendiknas, Pengembangan Pendidikan Budaya dan Karakter Bangsa, 2010, Jakarta : Puskur.

Lina, Neneng dan Sarbini, 2011, Perencanaan Pendidikan, Bandung: CV Pustaka Setia. 
Lirboyo, Santri, 2015, Kajian dan Analisis Ta'lim Muta'alim, Kediri: Santri Salaf Press. Matsuki dkk, 2008, Manajemen Pondok Pesantren, Jakarta: Diva Pustaka.

Munirah, 2015, "Sistem Pendidikan Di Indonesia: Antara Keinginan dan Realita," Auladuna Jurnal Pendidikan Dasar Islam Vol 2 no. 2.

Rahman, Muhammad Aulia, 2002, Pengantar Ilmu dan Metodologi Pendidikan Islam, Jakarta: PT.Intermasa.

Rochaety, Eti, 2005, Sistem Informasi Manajemen Pendidikan, (Jakarta: PT Bumi Aksara.

Rusdiana, dan A. Qiqi Yuliati Zakiyah, 2014, Pendidikan Nilai Kajian Teori dan Praktik di Sekolah, CV Bandung: Pustaka Setia.

Said, Nur, 2016, Santri Membaca Zaman, Kudus: Santri Menara Pustaka.

Syabiti, Ibi \& Nizar Ali, 2009, Manajemen Pendidikan Islam: Ikhtiar Menata Kelembagaan Pendidikan Islam, Bekasi: Pustaka Isfahan.

Usman, H. Kahar, Sosiologi Pendidikan, Buku Daros

Wibowo, Agus, 2013, Manajemen Pendidikan Karakter di Sekolah (Yogyakarta: Pustaka Pelajar.

Yasin, Fattah, 2010, Dimensi-dimensi Pendidikan Islam, Malang: UIN Malang Press. 